\section{To: (Receiving Organization) \\ Distribution}

5. Proj./Prog./Dept./Div.:

Project $\mathrm{W}-211$ 83100/TWRS Upgrades

6. Design Authority/ Design Agent/Cog. Engr.: JH Bussel1
3. From: (Originating Organization)

8. Originator Remarks:

Attached is the Year 2000 Compliance Assessment for Project W-211.

11. Receiver Remarks:

11A. Design Basel ine Document?

[] Yes

$[X]$ No

\section{Related EDT No.: \\ $N / A$}

7. Purchase Order No.:

$$
N / A
$$

9. Equip./Component No.:

$$
N / A
$$

10. System/Bldg./Facility: Year 2000/241-G

12. Major Assm. Dwg. No.: $\mathrm{N} / \mathrm{A}$

13. Permit/Permit Application No.: $\mathrm{N} / \mathrm{A}$

14. Required Response Date: $N / A$

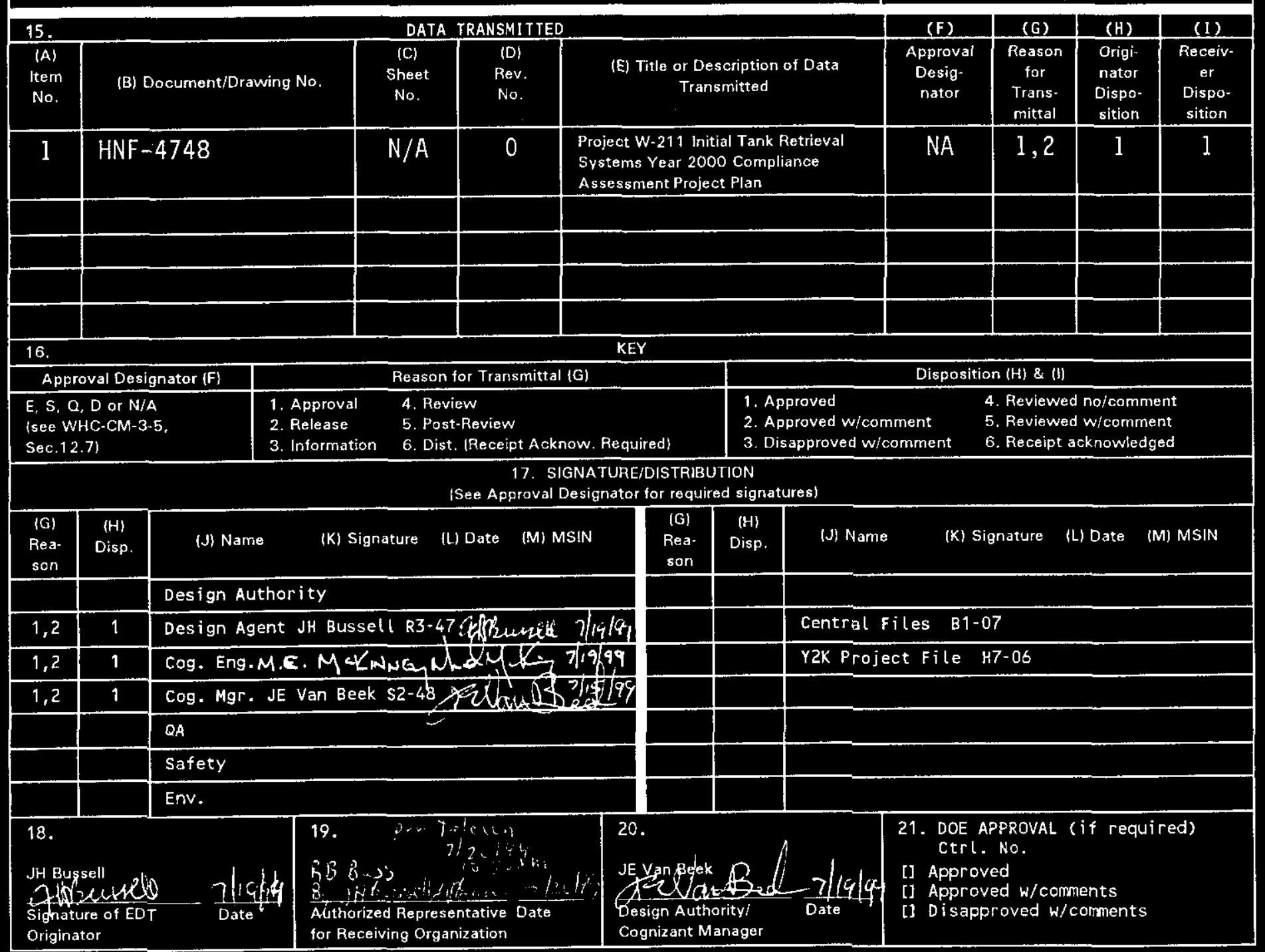




\title{
PROJECT W-211 INITIAL TANK RETRIEVAL SYSTEMS YEAR 2000 COMPLIANCE ASSESSMENT PROJECT PLAN
}

\author{
J. H. Bussell \\ Numatec Hanford Co. \\ Richland, WA 99352 \\ U.S. Department of Energy Contract DE-AC06-96RL13200

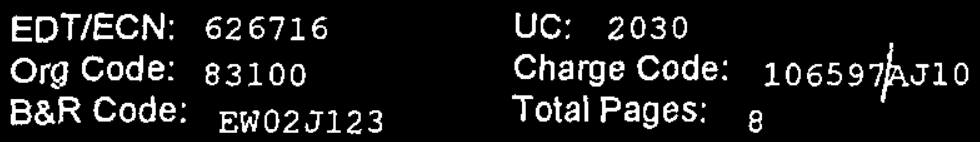 \\ Key Words: Year 2000, Y2K, Project W-211
}

Abstract:

This document contains a limited assessment of Year 2000 compliance for Project $W-211$. Additional information is provided as a road map to project documents and other references that may be used to verify Year 2000 compliance.

TRADEMARK DISCLAIMER. Reference herein to any specific commercial product, process, or service by trade name, trademark, manufacturer, or otherwise, does not necessarily constitute or imply its endorsement, recommendation, or favoring by the United States Government or any agency thereof or its contractors or subcontractors.

Printed in the United States of America. To obtain copies of this document, contact: Document Control Services, P.O. Box 950, Mailstop H6-08, Richland WA 99352, Phone (509) 372-2420; Fax (509) 376-4989.

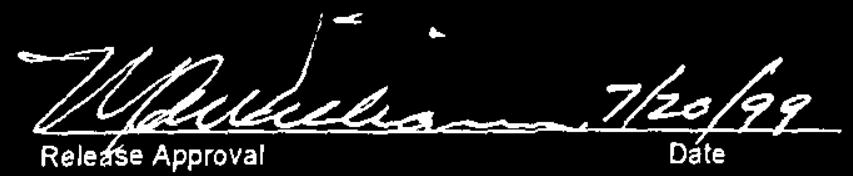

Approved For Public Release 


\title{
PROJECT W-211
}

\section{INITIAL TANK RETRIEVAL SYSTEMS}

\section{YEAR 2000 COMPLIANCE ASSESSMENT PROJECT PLAN}

\author{
Prepared by: \\ JH Bussell \\ Numatec Hanford Co.
}

July 16, 1999 


\section{TABLE OF CONTENTS}

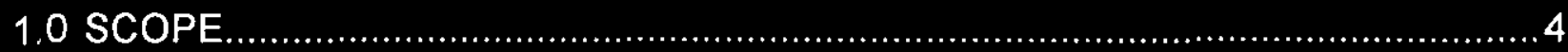

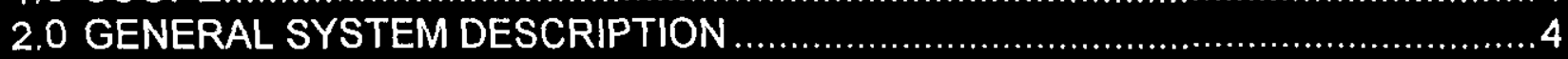

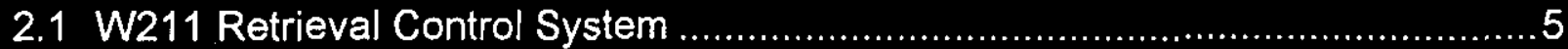

2.2 Variable Speed Drives Used for Mixer Pumps and Other Motors......................... 5

2.3 Other Process Instruments ................................................................................. 5

3.0 ASSESSMENT OF YEAR 2000 (Y2K) COMPLIANCE....................................

3.1 System Dates and Date Related Functions .................................................6

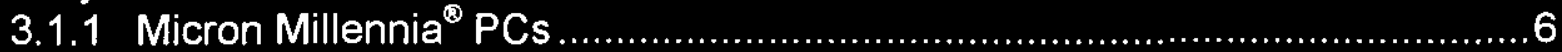

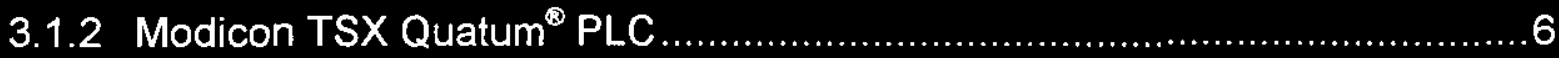

3.2 System Software for the System or Item .....................................................

3.2.1 Windows $\mathrm{NT}^{\circledR} 4.0$ Operating System ......................................................

3.2.2 Ci Technologies Pty Limited ${ }^{\oplus}$ (Citect) HMI Software ....................................

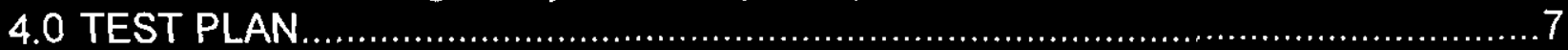

5.0 YEAR 2000 (Y2K) ACTIVITIES, MAJOR MILESTONES, AND DELIVERABLES .....7

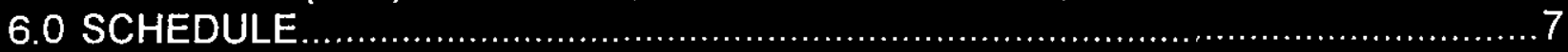

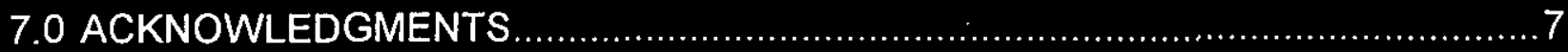

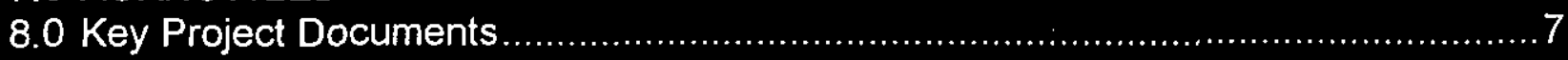




\subsection{SCOPE}

This assessment describes the potential Year 2000 (Y2K) problems and describes the methods for achieving Y2K Compliance for Project W-211, Initial Tank Retrieval Systems (ITRS). The purpose of this assessment is to give an overview of the project. This document will not be updated and any dates contained in this document are estimates and may change. The scope of project W-211 is to provide systems for retrieval of radioactive wastes from ten double-shell tanks (DST). Waste retrieval systems will be installed in tanks 102-AP, 104-AP, 105-AN, 104-AN, 102-AZ, 101-AW, 103-AN, 107-AN, 102-AY, and 102-SY. The current tank selection and sequence supports phase I feed delivery to privatized processing plants.

A detailed description of system dates, functions, interfaces, potential Y2K problems, and date resolutions can not be described since the project is in the definitive design phase. This assessment will describe the methods, protocols, and practices to assure that equipment and systems do not have Y2K problems.

\subsection{GENERAL SYSTEM DESCRIPTION}

The retrieval systems include the mixer and transfer pumps necessary to mobilize and remove solids and supernate from the DSTs, support equipment and facilities needed for operating and monitoring the retrieval equipment, and any project specific waste tank modifications and utility upgrades.

The scope of work to be accomplished by ITRS includes providing and installing the following:

c Sludge mobilization assemblies (mixer pumps).

c Operator stations that include functions to monitor, alarm, and control retrieval systems for each tank as well as interface with tank farms and the transfer lines.

c Means of determining the distance to the bottom of the tank where the pumps and equipment will be installed.

r Means of measuring the effects and results of mixer pump operations.

- Instrumentation to measure flow, pressure, density, and temperature to determine the physical characteristics of the waste slurry prior to and/or during transfer, dependant on the receiving station requirements. Density measurements are not required for tanks 102-AP and 104-AP. In support of waste feed acceptance by the privatized processing plants, tanks 102-AP and 104-AP will be well mixed and well characterized prior to transfer.

Interface with existing instrumentation critical to the mixing or transfer process to monitor tank waste and air space temperatures, and waste levels within the tank. 
- Internal tank equipment upgrades, where required, with sufficient structural strength to withstand jet forces that will result from retrieval operation.

- Pumps for transferring waste out of the tanks.

- Standard containers for disposal of contaminated components and soil.

- Utilities required for retrieval operations (electrical power, water, telecommunications, etc.

System to maintain temperatures within the tank to acceptable levels, if required.

- Dilution capability, if not already available, to bring waste properties into acceptable range for transfer.

\subsection{W211 Retrieval Control System}

The W211 Retrieval Control System (RCS) consists of four parts:

1. Micron Millennia Pro $P C^{\circledR}$ with

- Pentium Pro ${ }^{\oplus} 200 \mathrm{MHz}$ CPU

- American Megatrends Inc. ${ }^{\circledR}$ (AMI) Basic Input-Output System (BIOS) AMIBIOS ${ }^{\circledR}$ Ver. 1.00.02.CS15

c Manufactured during July 1996

2. Operating System: Windows $N T^{\circledR} 4.0$ with Service Pack 3.0

3. Ci Technologies Pty. Limited ${ }^{\circledR}$ Human Machine Interface Software

4. Modicon TSX Quantum ${ }^{\oplus}$ PLC

RCS for tanks 105-AN, 104-AN, 102-AZ, 101-AW, 103-AN, 107-AN, 102-AP, 104-AP, 102-AY, and 102-SY will be installed after January 1, 2000.

\subsection{Variable Speed Drives Used for Mixer Pumps and Other Motors}

Variable speed drives employ microcontrollers and digital communication links to permit monitoring of drive frequency, motor phase current, motor phase voltage, and other alarm conditions. In general, variable speed drives do not contain real time clocks.

\subsection{Other Process Instruments}

Other process instrumentation may contain smart instruments that contain microcontrollers or microprocessors. In general, these types of instruments do not contain real-time clocks. 


\subsection{ASSESSMENT OF YEAR 2000 (Y2K) COMPLIANCE}

\subsection{System Dates and Date Related Functions}

\subsubsection{Micron Millennia ${ }^{\circledR}$ PCs}

All Micron ${ }^{\otimes}$ PCs created after $8 / 26 / 96$ are Y2K compliant. Both PCs being used for the RCS were manufactured during July 1996. Thus, they are not certified as Y2K compliant by Micron ${ }^{\circledR}$. However, these computers will maintain dates beyond 2000 after adjustment of the date on January 1,2000. This information was obtained at URL: http://support.micronpc.com/year2000/. Micron uses the National Software Testing Laboratory (NSTL) to test and certify their systems (posts 8/26/96 systems). NSTL offers a free Y2K testing program, Ymark2000, to analyze a PCs ability to handle dates in the $21^{\text {st }}$ century. This program, version 98.02.15, was run on both PCs and both passed. A summary of the test results are listed below:

Testing for Motorola MC146818 compatibility:

- MC146818 compatible hardware clock.

Testing for progression to Year 2000:

$$
\text { January 01, } 2000 \quad \text { 00:00:01 }
$$

- Progression to Year 2000 occurs

Testing $21^{\text {st }}$ century leap year:

$-21^{\text {st }}$ century leap year test passes

Summary: (0)

- This system correctly supports the Year 2000.

A description of this program can be found at URL: http://wuw.nstl.com.

\subsubsection{Modicon TSX Quatum ${ }^{\circledR}$ PLC}

The PLC and Modsoft ${ }^{\circledR}$ programming software was tested by Modicon ${ }^{\circledR}$ and passed all Y2K test criteria listed below:

1. December 31 st, 1999 to January 1st, 2000 (both Powered and battery backed)

2. Each Months rollover verified

3. Leap year functionality tested (February 29th, 2000)

4. Set Date functions within the year 2000 and thru 2030

5. Power Cycles at rollover points

6. Illegal Set Date values

7. Special critical dates (i.e., 12/31/1998, 01/01/1999, 9/9/1999, 12/31/1999, 2/28/2000,

$3 / 1 / 2000,12 / 31 / 2027,01 / 01 / 2030)$

8. Date Window (01/01/1998 to 01/01/2030).

Further information on Y2K compliance can be found at these URLs: http://www.modicon.com and http://www.schneiderautomation.com. 


\subsection{System Software for the System or Item}

\subsubsection{Windows $\mathrm{NT}^{\circledR}$ 4.0 Operating System}

Microsoft Corporation certifies that Windows $\mathrm{NT}^{\otimes}$ is $\mathrm{Y} 2 \mathrm{~K}$ compliant, with minor issues. A complete definition and solutions for the above issues is listed at URL: http://www.microsoft.com/technet/year2k/product.asp. After reviewing the complete information on these issues, it is recommended that the presently available patches not be used. Instead, it is recommended to wait until the next service pack is released, which will contain these fixes. The issues are so specific that they are not a concern for affecting the RCS.

\subsubsection{Ci Technologies Pty Limited ${ }^{(C i t e c t) ~ H M I ~ S o f t w a r e ~}$}

Citect was initially designed to handle transitions into the $21^{\text {st }}$ century. Initial testing uncovered two minor date related anomalies, which have since been corrected. The Citect software relies on all components in the RCS to correctly handle date issues, thus if any of the other components have a problem Citect may not operate correctly. However, the four components of the RCS that are listed in section 2.1 have been shown to be $\mathrm{Y} 2 \mathrm{~K}$ compliant as described in sections $3.1 .1,3.1 .2,3.2 .1$, and in this section. Further information onY2K issues can be found at URL: http://wmw. citect.com.

\subsection{TEST PLAN}

No special testing $\mathrm{Y} 2 \mathrm{~K}$ testing is planned. However, all applicable $\mathrm{Y} 2 \mathrm{~K}$ related dates will be tested as part of the system acceptance testing.

\subsection{YEAR 2000 (Y2K) ACTIVITIES, MAJOR MILESTONES, AND DELIVERABLES}

No special activities are planned.

\subsection{SCHEDULE}

No special activities are planned for project. The first system, tanks 102-AP and 104-AP, will be installed after January 1, 2000.

\subsection{ACKNOWLEDGMENTS}

The author wishes to acknowledge Eric Johnson of Fluor Daniel Northwest, Inc. for providing detailed information on the components of the RCS and the material in the appendices.

\subsection{Key Project Documents}

Clayton, R.E., 1995, "QA Program for W-211 Initial Tank Retrieval System," WHC-SD-W211-QAPP-002, Revision 1, Westinghouse Hanford Co, Richland, Washington.

Hall, L.N., 1998, "Project Specific Quality Assurance Plan Project W-211 Initial Tank Retrieval System," HNF-SD-W211-QAPP-001, Revision 2, Fluor Daniel 
Northwest, Richland, Washington.

Kidder, R.J., 1993, "Preliminary Safety Equipment List for 101SY ITRS Project W-211," WHC-SD-W211-SEL-001, Revision 0, Westinghouse Hanford Co., Richland, Washington.

Kidder, R.J., 1994, "Preliminary Safety Equipment List for ITRS Project W-211," WHC-SD-W211-002, Revision 0, Westinghouse Hanford Co., Richland, Washington.

Nguyen, Q.H., 1997, "Programmer's Guide for Project W-211, DST 241-SY-102 Retrieval Systems Operator Interface," HNF-SD-W211-SDR-001, Revision 0, 1997, Fluor Daniel Northwest, Inc., Richland, Washington.

Rieck, C.A., 1993, "Conceptual Design Report Initial Tank Retrieval System for Project W-211," WHC-SD-W211-CDR-001, Revision 0, Westinghouse Hanford Co., Richland, Washington.

Rieck, C.A., 1994, "Conceptual Design Report Initial Tank Retrieval System Project W-211," WHC-SD-W211-CDR-002, Revision 0, Westinghouse Hanford Co., Richland, Washington.

Rieck, C.A., 1997, "Functional Design Criteria Project W-211 Initial Tank Retrieval System," WHC-SD-FDC-001, Revision 3A, Numatec Hanford Co., Richland, Washington.

Rieck, C.A., Block, G.A., 1998a, "AP102 \& AP104 Retrieval Control System Qualification Test Proceedure," HNF-3334, Revision 0, Numatec Hanford Co, Richland, Washington.

Rieck, C.A., 1998b, "Interface Document, Project W-211, Initial Tank Retrieval System," HNF-1507, Revision 0, Numatec Hanford Co, Richland, Washington.

Rieck, C.A., Johnson, E.D., 1998c, "Initial Tank Retrieval System Retrieval Control System Programmers Guide for AP Farm," HNF-3298, Revision 0, Numatec Hanford Co. and Fluor Daniel Northwest, Inc., Richland, Washington.

Rieck, C.A., 1998d, "Project Management Plan for Initial Tank Retrieval System Project W-211," HNF-3333, Revision 0, Numatec Hanford Co., Richland, Washington.

Rieck, C.A., 1998e, "Project W-211 ITRS \& Retrieval Control System Software Configuration Management Plan," HNF-SD-CSCM-036, Revision 1, Numatec Hanford Co., Richland, Washington.

Rieck, C.A., 1998f, "Project W-211 Initial Tank Retrieval System Description of Operations for 241AP102 \& 241AP104," HNF-3514, Revision 0, Numatec Hanford Co., Richland, Washington. 